\title{
A STUDY ON THE POSSIBLE EFFECTS OF HORIZONTAL AGREEMENTS BETWEEN AIRLINES REGISTERED IN TURKEY: A MANAGERIAL PERSPECTIVE
}

\author{
YATAY ANLAŞMANIN TÜRK HAVAYOLU İSLETMELERINNE MUHTEMEL \\ ETKİLERININ YÖNETSEL AÇIDAN İNCELENMESI
}

Ender GEREDE ${ }^{1}$

$\ddot{O} \mathbf{z}$

Avrupa Topluluğu Adalet Divanı bazı AB üyesi ülkelerin ABD ile yaptıkları açık semalar anlaşmalarındaki "sahiplik ve yönetimde etkin kontrol" hükümlerinin Roma Anlaşmasına aykırı olduğu sonucuna varmıştır. Avrupa Birliği Komisyonu, bu kararın bir gereği olarak, üçüncü tarafların üye ülkeler ile imzaladıkları tüm ikili havayolu taşımacılığı anlaşmalarının değiştirilmesini istemekte ve üçüncü ülkelere "yatay anlaşma" adı verilen bir anlaşma metni teklif etmektedir. Anlaşmayı parafe etmiş olan Türkiye'nin bu anlaşmayı imzalaması pazardaki rekabet yapısını ve Türk Tescilli Havayolu İşletmelerinin rekabet stratejilerini etkileyecektir. Bu çalışmada, yatay anlaşmanın getireceği değişim, bu değişimin yaratacağı doğrudan ve dolaylı sonuçlar ve bu sonuçların Türk Tescilli Havayolu İşletmelerini yönetsel açıdan nasıl etkileyeceği tartışılmakta ve bazı öneriler getirilmektedir.

Anahtar Kelimeler: Yatay Anlaşma, Havayolu rekabet stratejileri, İkili havayolu taşımacılığı anlaşmaları, Havayolu yönetimi, Sivil havacılık yönetimi.

\begin{abstract}
The European Court of Justice declared that the nationality clauses in the open sky agreements among member states with the US that restrict international traffic rights to the national flag carriers of the countries concerned, are contrary to the Treaty of Rome. The Commission therefore desires to negotiate an agreement named Horizontal Agreement on behalf of the member states, in order to bring all existing bilateral air services agreements between member states and a given third country in line with the European Community Law. Turkey initiated this agreement and possibly this will affect the market conditions and the competition strategies of airlines registered in Turkey. Therefore, this study examines the changes that may result from the Horizontal Agreement, how these outcomes will have an effect on the competition strategies of airlines registered in Turkey. Some suggestions are as well presented.
\end{abstract}

Keywords: Horizontal Agreement, Airline Competition Strategies, Bilateral Air Services Agreements, Airline Management, Civil Aviation Management

\footnotetext{
${ }^{1}$ Doç.Dr., Anadolu Üniversitesi Havacılık ve Uzay Bilimleri Fakültesi, Sivil Hava Ulaştırma İşletmeciliği Bölümü, egerede@anadolu.edu.tr
} 


\section{Introduction}

Air transportation, which has great benefits for the humanity in economic, social, cultural and political fields, has been one of the most internationalized industries in the world (O'Connor, 1995, p.14; Oum and Yu, 1998, p.1). However, air transportation has also been one the most tightly regulated sectors in the face of globalization, compared to other international sectors. Yet, this sector has been increasingly globalizing across the world (Doganis, 2006, p.27).

The United State of America (USA) has been the country that most supported liberalization policies and strived for the liberalization of the airline industry in the world (Wensveen, 2007, pp. 478-479; Doganis, 2006, pp. 32-33; Elek et al., 1999, p. 144; Antoniou, 2001, p.70). Even the liberalization in the domestic market of the USA has influenced other countries and fostered the inclination towards liberalization across the world (Button et al., 1998, p.11; Chan, 2000, p.513).

Today, the most liberal airline market is the regional market launched by members of the European Union (EU). The entry into force of the third liberalization package in 1997 was a turning point in the liberalization of the EU airline market. With this progress, the strong liberalization in the EU started affecting the practices in the world.

In this process, the Court of Justice of the European Communities (CJEC) decided that the 'ownership and control' provisions in the 'open skies agreements' (highly liberal bilateral air services agreements - BASAs), which some of the EU members signed with the US, were against the EU legislation. This decision required that all BASAs that third parties signed with the Member States were amended in line with the EU legislation. For making these amendments, the EU has suggested that third countries conclude a multilateral agreement, known as the horizontal agreement (HA).

Meanwhile, Turkey has induced full membership negotiations with the EU. In Turkey's adaptation process to the EU, one of the most disputed issues in the field of aviation has been the HA that the EU proposed to Turkey. The negotiations that commenced in 2003 accelerated in 2009, and the agreement was initiated in March 2010 following about twenty negotiations. The agreement was at the phase of signing.

In the process of full membership, Turkey will adapt to economic and technical regulations that govern the aviation industry of the EU. Turkey has made significant progress in adapting to technical regulations related to aviation safety. With regard to economic regulations, the HA negotiations have reached a very important level. When full membership is achieved, the Airlines Registered in Turkey (ARTs) will have entered the most liberal airline market of the world. Nevertheless, how will the ARTs be affected if the HA, which is expected to change considerably the situation of the EU - Turkey airline market, is signed before Turkey becomes a full member to the EU? This is a very important research problem. We are faced with obligatory adaptation requirements arising from full membership on one hand, and a relatively young and inexperienced airline industry that has recently entered the liberal competition environment on the other hand. The aims of this study, in line with the research problem defined above, are as follows:

- to provide an overview of how market entry regulations developed and to summarize the current situation in the airline market between the EU Member States and Turkey, with regard to the concept of 'substantial ownership and effectively control' regulations (SOEC)

- to explain the characteristics and benefits of the HA proposed by the EU, and

- to examine possible effects of the HA on ARTs from the perspective of management.

While seeking answers to these questions, this study focuses on the effects of the HA on management and competition strategies of airlines rather than on its legal or economic effects on the airline industry. We believe that the research on above questions would enable managers in airlines to take better decisions related to strategic planning and other management functions. 


\section{Method}

SOEC regulations in the airline market between the EU Member States and Turkey is based on the analysis of qualitative data. In this study qualitative content analysis was used. The documents analyzed are all BASAs that the Republic of Turkey signed with the EU Member States, the reports, minutes and memorandum of understanding of negotiations with each country before these agreements were signed, and the reports, minutes and memorandum of understanding of negotiations that made amendments on agreements after they were signed. All these texts were examined and described individually.

The author also received opinions of the ARTs in order to define the possible effects of the HA on ARTs in terms of their strategies. The ARTs operating scheduled flights in Europe were included in the study. These companies were Turkish Airlines, Pegasus Airlines and SunExpress. Atlasjet and Onur Air, which operate scheduled flights to markets other than Europe, were excluded from the study.

The Turkish Private Aviation Enterprises Association (TPAEA) has been taking part in the negotiations between the Commission and Turkey, on behalf of the private sector. The TPAEA experts analyzed the issue, receiving the opinions of all private ARTs before the inception of negotiations. That is why the TPAEA was also included in the study in order to foster the internal reliability of the study by having better understanding of the private-sector opinion. In addition to the TPAEA; Turkish Airlines, Pegasus Airlines and Sun Express were interviewed between April and June 2011 in Istanbul and Antalya. Semi-structured interview method was used to collect the data.

An interview form that comprises of three questions was used during the interviews. The questions in the form were as follows:

1. What will the horizontal agreement change in the implementation of BASAs?

2. What will be the positive effects of the horizontal agreement on the Airlines Registered in Turkey? How and why will these effects emerge?

3. What will be the negative effects of the horizontal agreement on the Airlines Registered in Turkey? How and why will these effects emerge?

All interviews were conducted by the same researcher in order to assure consistency. Further, the length of interviews was long to the extent possible, average one hour, to strengthen plausibility; and the replies of interviewees were noted down. In order to improve validity, the author asked further questions to clarify the issues that were ambiguous at the end of the interview and tried to confirm whether the replies were understood accurately. When selecting the interviewees in the companies included in the study, purposive sampling method was used to improve validity. The interviewees were selected among senior managers employed in international relations and marketing departments of companies, who have knowledge on the research topic and are familiar with BASAs. The number of interviewees is ten.

Norway and Switzerland were included in the study although they are not members of the EU. These countries participated in the single market where there are regulations concerning air transportation in the EU. Croatia, as a candidate country, was also included in the study. This study does not cover Cyprus and Iceland as Turkey does not have BASAs with these countries. 


\section{Economic Regulations in International Air Transportation Market}

\subsection{Bilateral air services agreements}

In order to operate scheduled flights in the international area, signatory countries are required to define the conditions of these flights with mutual agreements. The basis for this requirement is the Paris Convention signed multilaterally in 1919. This convention granted national sovereignty to countries concerning the aerial area over their land frontiers (Doganis, 2002, p.30). Thus, air transportation in the international area became dependent on the permission of another country. As air transportation was growing rapidly, there emerged the need for a multilateral agreement at the international level in 1940s. In 1944, 52 countries came together in Chicago for this purpose, but were not able to conclude a multilateral agreement (Doganis, 2002, p.30; Khee-Jin Tan, 2006, pp.432-433).

Because the parties could not reach a 'multilateral' agreement on economic regulations of international air transportation in the Chicago Convention, they were required to handle these issues 'bilaterally'. These agreements signed between contracting parties are known as Bilateral Air Services Agreements (BASAs) (Doganis, 2002, p.33).

At this point, there is need to define the term 'airline market' as BASAs basically regulate this market. The airline market is the place where provider of air transportation between two points come together with current or potential passengers, loads and mails to be transported commercially between these two points (ICAO, 2004:4.1.1). Turkey and Germany constitute an example for the market of a country pair; and Istanbul and Paris constitute an example for the market of a city pair.

These agreements basically regulate to which markets air transportation services reach (market access), how many airlines can be designated to use the right to market access and under which conditions the airlines use it (market entry), the amount of production in this market (capacity), and how to set the price of services offered (price). The characteristics of these regulations gain in BASAs determine to what extent the said market is designed tightly or liberally.

Market access determines the points where international air transportation service will be provided, in other words, which markets are open to air transportation. The parties define market access by identifying the departure points in a country and arrival points in the other country. The alternative ways of market access are referred to as 'traffic rights' in the literature (Doganis, 2006, p.28).

The regulations regarding the use of market access right is known as the dimension of 'market entry'. The market entry dimension has two components. One of them is the number of airlines that use the right to market access on behalf of the contracting countries. The other one is the nationality of the owner of a company that use this right and the nationality of people playing a role in the management of the said company. As the focus of this study is on the latter, it will be detailed in the next part of the study. A country signing the BASA authorizes one or more airline companies to use "the right to market entry", in accordance with related regulations. This procedure is known as 'designation' (Doganis, 2002, p.59, 31).

The third dimension of economic regulation is related to the amount of capacity that an airline offers to the market and how this capacity is determined. The capacity offered is based on the number of seats and frequency. The number of seats is dependent on the type of airplanes. Frequency is measured by daily and weekly number of flights (ICAO, 2004:4.2-1; ICAO, 1999:3.1$3.8)$.

The final dimension of economic regulation is price tariffs. This dimension covers regulations on how airlines determine costs for the carriage of passengers, luggage and cargoes. The most important components of price tariff are "method for the approval of tariffs", "factors to be considered in price setting", "tariff setting tools" and "duration of application to tariffs" (ICAO, 
2004:4.3-1-4.3-2). These components directly influence the strategies and efficiency of an airline management.

Above considerations show that economic regulations in BASAs have direct impacts on managerial functions of airlines. Market access regulations determine which products are offered (to which city pair markets an airline provides service); market entry determines whether this product is produced by the said airline; capacity determines the amount of production and price tariff determines the marketing price of the product. Thus, competitive strategies and managerial activities of airlines will be affected by these regulations.

We observe that the international scheduled air transportation has been gradually liberalizing for 30 years. The highly liberal, aggressive and expansionist international aviation policies of the US have triggered this process and played an important role in the deepening and expansion of the process (Doganis, 2006, pp.32-33; Elek et al., 1999, p.144; Morrell, 1998, p.44).

Below is summarized the components related to economic regulations, which have been liberalized, and the degree of liberalization achieved throughout this process (Morrell, 1998, p.44; Zhang and Chen, 2003, pp.31-32,42; Staniland, 1997, p.201; Findlay, 2003, p.211; Forsyth, 2001, p.44; Doganis, 2006, pp.31-45):

- The constraints on market access were untightened, the number of destinations were increased, third or fourth traffic rights were assigned to all city pairs, progress was achieved in granting the fifth traffic right, the number of city pairs where the fifth traffic right is used was increased,

- The number of airlines that are authorized to enter the market had first been increased from one to two in both contracting parties, then the number was augmented more, the number of airlines to be designated became independent of the market to be accessed, the restriction on the number of airlines to be designated was totally removed,

- The airlines were provided with the opportunity to determine flexibly and mutually the capacity to be offered in a market (previously the capacity was predetermined by state authorities), pooling agreements were forbidden, and the airline itself is now authorized to determine the capacity in line with market conditions and revise the capacity dynamically over time,

- Price setting became independent of International Air Transport Associations (IATA) processes, the role of state authorities in price setting was reduced, and the price may now be determined solely by airlines under liberal market dynamics.

As explained above, the four dimensions of economic regulation in international air transportation has been increasingly liberalizing. The endpoint of this liberalization is referred to as "open skies agreements" in the literature, and these agreements are generally bilateral (Brueckner and Pels, 2007, p.14 ; Khee-Jin Tan, 2006, p.437 ; Doganis, 2006, pp.40-45). There have nevertheless been some attempts to make multilateral liberal open skies agreements known as APEC, MALIAT and ASEAN (Khee-Jin Tan, 2006, pp.435-441). The point that the EU airline market reached is a real example of a multilateral open skies agreement. However, in this process, there have still been some practices that are subject to tight regulations. These are provided below (Doganis, 2006, pp.51-52):

- Carrying passengers or cargo between two different countries - not allowed to enjoy the $7^{\text {th }}$ traffic right in market access,

- Carrying passengers or cargo in domestic lines of a foreign country - not allowed to to enjoy the $8^{\text {th }}$ traffic right or cabotage,

- The SOEC regulations preserving their traditional structure.

The components listed above are tightly regulated anywhere in the world, excluding the single market formed by the EU members. Even the US, implementing the most liberal aviation policies in the world, takes a highly protective stance with regard to these three components 
(Doganis, 2006, p.52; Haanappel, 2001, p.90). This may be perceived as an effort to protect the national airline industry, the national identities of airlines and the elements that constitute the national identity. Since the focus of this study is on "substantial ownership and effective control", the other points are not dealt with herein.

\subsection{Substantial ownership and effective control}

Substantial ownership and effective control (SOEC) is a component of the dimension of market entry. This component defines the qualifications that an airline company to enjoy the right to market entry must hold. The companies that do not bear these qualifications cannot enter the market.

The concept of SOEC does not have a widely accepted definition as an economic term (Sang-Eun Oh, 2005, p.11; Mestral, 2005, p.5). It may be useful to divide the SOEC into two subcomponents to make the term more comprehensible. This regulation is first related to the ownership structure of an airline. The second sub-component is related to whom the company is managed by.

The ownership structure of an airline is determined by the amount of shares that provide the right to vote. Traditionally, it has been required that "substantial ownership" of an airline to enter the market is held by nationals of the said contracting party (Doganis, 2006, p.20; Khee-Jin Tan, 2006, p.11). In this case, there is need to clarify the concept of "substantial ownership". The amount of shares that corresponds to a "substantial" part of ownership varies from one country to another. For instance, this amount is $75 \%$ in the USA and $51 \%$ in the EU countries (Sang-Eun Oh, 2005, p.12; Hanlon, 2007, p.300; Doganis 2006, p.55).

The other sub-component of the regulation is "effectively controlled", which is concerned with the nationality of actors playing an effective role in management of an airline. The nationality of the executive board members, president of the board and top executive member, who are authorized to take strategic decisions, is taken into consideration (Sang-Eun Oh, 2005, p.13).

It has traditionally been expected that an airline using the right to market entry is owned by nationals of the country where it is established and managed under effective control of nationals of the said country (Doganis, 2006, p.52; Khee-Jin Tan, 2006, pp.433-434,441; Sang-Eun Oh, 2005, p.9). The most significant outcome of this practice is preventing foreign nationals from carrying out air transportation services by acquisition of or launching an airline in the country. It is worth considering why the SOEC regulations remain as tight as they used to be, while many components of economic regulations have been liberalized. The reasons may be summarized as follows (SangEun Oh, 2005, p.10):

- The aspiration to use airlines for national security and defense purposes,

- The need to govern national trade and tourism sector,

- The need to create employment opportunities,

- The need to control aviation safety directly,

- The need to control and observe public interest for national development purposes,

- The fact that national airlines are regarded as the symbol of national sovereignty.

The above factors were also seen as an obstacle to the liberalization of other components for long years. Despite its liberal aviation policies, the US has had tight regulations for SOEC because the country wants to have a civil reserve air fleet in case of a war, a desire which is the result of the Korean War of 1951 (Sang-Eun Oh, 2005, pp.10-11). It is clear that air transportation is an important defense tool in wars.

Another important reason for tight regulations is the idea that the demand for air transportation between two countries emerges from the need of those two countries, and thus the benefits of this demand should be shared by the two countries (Khee-Jin Tan, 2006, p. 434). This 
policy has resulted in constraining the ownership of foreigners to $49 \%$ in many countries (Khee-Jin Tan, 2006, p.437). In the US, the rate of constraint is $25 \%$.

The structure of ownership did not lead to a complicated situation in 1940s and 50s when this regulation was first introduced and implemented, as almost all airlines were state-owned in those years. Nevertheless, in the globalized and liberalized airline market of our present day, the private airlines make the situation complicated. The equity securities of privatized airlines are traded in the stock exchange, and can be bought by foreigners. That is why, today, it is more important who manages an airline rather than who owns it (Sang-Eun Oh, 2005, pp.11-12 ; Doganis, 2006, p.56). For instance, in order for an airline to obtain operating license in the US, at least one third of its top executives are required to be US citizens (Sang-Eun Oh, 2005, pp.13-14).

In international airline markets, the SOEC is the primary component that is subject to the tightest bilateral regulations (Chang et al., 2004, p.161; Haanappel, 2001, p.90; Doganis, 2006, p.52). Market entry regulations are entirely liberal only in the EU countries in multilateral terms. There have also been some liberalization tendencies with respect to SOEC regulations. The most commonly used method in this liberalization process is demanding that the principal place of business of the airline designated is located in that country rather than stipulating that the SOEC is held by its nationals (Doganis, 2006, p.55, 62).

Today, the EU has become a "union" in the real sense in both political and economic terms, and the most liberal airline market is established within the union. The fully liberal market conditions were achieved in three stages and in a ten-year process (1987-1997). The "First Package" was introduced in December 1987, and followed by the "Second Package" in June 1990 and the "Third Packge" in January 1, 1993 (Chang and Williams, 2002, p. 29).

After the third package, obtaining a license became subject to certain standards, and the market access, market entry, capacity and price were entirely liberalized. What distinguishes the process in the EU from other liberalization practices in the world is that the SOEC regulations have also become liberal for the EU members. The most radical change brought in April 1997 enabled the use of $8^{\text {th }}$ traffic right or domestic lines transportation, in other words permitted cabotage (Doganis, 2006, pp.46-47; Morrell, 1998, p.46). As a result, the airline markets of different countries were merged under a single market, and the airlines were transformed into community carriers (Graham, 1997, p.228; Staniland, 1997, p.199).

Citizens of EU Members States can currently launch or acquire an airline in whichever country they want, on condition that they comply with technical regulations. Airlines can operate flights between any two points and in whichever frequency and capacity they wish, and set the price of their services entirely on their own will.

The final relevant rules in the EU were adopted with Regulation (EC) no. 1008/2008 of September 29, 2008. This regulation sets out all conditions required for an airline to obtain operating license and to operate flights. An air carrier is allowed to apply to any Member State to obtain a license provided that its center of business is located in one of the member countries. The air carrier is required to satisfy the following conditions to obtain an operating license (European Parliament and the Council, 2008):

- The principal place of business of the air carrier is located in that Member State,

- The air carrier bears an Air Operator Certificate (AOC) granted by the civil aviation authority,

- The air carrier has at least one aircraft through ownership or dry lease agreement,

- Its main occupation is air transportation,

- Its company structure allows the fulfillment of requirements in the regulation,

- At least $50 \%$ of the company is owned by citizens of that Member State,

- Financial requirements are satisfied, 
- Insurance requirements are met,

- The air carrier has had a good reputation in the aviation sector.

Once they fulfill these conditions, nationals of a Member State may launch or acquire an airline company in another Member State.

\section{The Horizontal Agreement}

\subsection{The History of legislative regulations laying the ground for the Horizontal Agreement}

In the late 1990s, the EU Commission drew attention to the fact that the Member States were making individual open skies agreements with third parties although the Community had a highly liberal market. The Commission considered that the open skies agreements that the Member States signed with the US was jeopardizing the single market within the EU (Doganis, 2006, p.53).

Both parties were adopting policies for the liberalization of international air transportation. Thus, the above disturbance of the Commission may seem pointless; however, a thorough evaluation shows that the Commission had right. For, through liberal agreements with individual member states, the US obtained many fifth traffic rights in the EU. Operating flights combining these points, the US airline companies seemed to have domestic flights within the Union. However, only the airlines designated by the signatory member state were allowed to operate flights to the US. In other words, when the EU is regarded as a single country, the number of community airlines to enjoy the right to market access was limited. On the other side, the US airlines almost had the right to $8^{\text {th }}$ traffic rights. In order to eliminate this, the Commission finally brought this issue before the CJEC in 1998.

The CJEC examined the case, and made its final decision on November 5, 2002. The CJEC concluded that it was a discrimination and against the EU law that the BASAs signed with the US granted the right to market entry only to the airlines designated by the signatory states rather than all community carriers (Doganis, 2006, p.53). As explained above, the airlines to be designated by a signatory member state were required to fulfill a preliminary requirement: the substantial ownership and effective control should have been held by nationals of the respective country. Nevertheless, the verdict of the Court means that all licensed community carriers had equal right to use market access rights between the Member States and the third parties. The result of this legal action regarding the open skies agreements signed with the US had far-reaching impacts and forced the Member States to amend all BASAs they signed with third parties. Yet, the Member States may continue negotiating the BASAs provided that these agreements are not against the court decision and the EU legislation (Kassim and Stevens, 2010, pp.170-171). The EU Commission decided that the amendments may be bilateral, or multilateral through agreements known as "horizontal agreements" (Sang-Eun Oh, 2005, p.37; Kassim and Stevens, 2010, p.172).

\subsection{Scope of the Horizontal Agreement}

With a view to facilitating the negotiations and ensuring standardization, the Commission devised a model agreement text titled the "Horizontal Agreement (HA)" (European Commission, 2006). The function of the HA is to amend the SOEC component merely in the market entry dimension of current BASAs. The HA does not intend to repeal or replace the existing BASAs. What is expected from the agreement is to ensure that all community carriers equally use the right to market entry provided in the BASA of any Member State (Khee-Jin Tan, 2006, p.447). This briefly means a unilateral liberalization of the SOEC component in the market entry dimension. HA, consisting of ten articles, regulates the abovementioned amendment in Article 2.

Article 4 of the agreement is about taxation of aviation fuel, Article 5 about liberal price setting for carriage between two member states, and Article 6 about compatibility with competition rules. These are additions to the existing agreements (Sang-Eun Oh, 2005, p.53). The remaining 
articles comprise provisions concerning annexes to the agreement, and amendment, entry into force and termination of

\section{Possible Effects of the Horizontal Agreement}

\subsection{Change Caused by the Horizontal Agreement}

The most basic change that the HA has brought is the replacement of the concept of "national air carrier" by "community air carrier". This refers to a change from a single Member State to the EU. The point that needs attention here is that the concept of "national air carrier" has not been eliminated entirely. The scope of the unit that owns the national air carrier was expanded: "an economic and political union" in place of "a country". The changes that the HA has led to are summarized in Table 1.

Table 1 .Changes in the Regulation on Ownership and Effective Control in Management

\begin{tabular}{|c|c|c|c|}
\hline & Before the HA & After the HA & Outcomes of the change \\
\hline \multirow{2}{*}{ Ownership } & \multirow{2}{*}{$\begin{array}{l}\text { Under the } \\
\text { ownership of } \\
\text { nationals of the } \\
\text { designating state }\end{array}$} & $\begin{array}{l}\text { Under the ownership } \\
\text { of nationals of any EU } \\
\text { Member State }\end{array}$ & $\begin{array}{l}\text { The concept of "national air carrier" } \\
\text { designated by Member States has been } \\
\text { transformed into "community carrier". }\end{array}$ \\
\hline & & $\begin{array}{l}\text { The airline established } \\
\text { in the territory of the } \\
\text { designating state }\end{array}$ & $\begin{array}{l}\text { The airline carrier to be designated is not } \\
\text { from a single Member State any more, but } \\
\text { from the EU. }\end{array}$ \\
\hline $\begin{array}{c}\text { Effective } \\
\text { control }\end{array}$ & $\begin{array}{l}\text { Under the control of } \\
\text { nationals of the } \\
\text { designating state }\end{array}$ & $\begin{array}{l}\text { Under the control of } \\
\text { nationals of any EU } \\
\text { Member State }\end{array}$ & $\begin{array}{l}\text { The unit that has substantial ownership and } \\
\text { effective control in management was a } \\
\text { country, but is now the EU as "an economic } \\
\text { and political union". }\end{array}$ \\
\hline
\end{tabular}

If the air carrier is established in the designating Member State, then the nationality of owner(s) is not taken into consideration. Any community carrier may take advantage of being established in any Member State. For instance, an airline established by the Greeks in Germany may take advantage of access opportunities to the German-Turkish market, as if it were a German air carrier. This means that the limited number of ARTs operating in Turkey will have to compete with a larger number of Community airlines.

The key regulation in this amendment is the definition of location where an air carrier is established. On condition that an air carrier proves that it is established in a Member State by which it wants to be designated and that there is no restriction on the number of carriers to be designated, then it may easily enter the airline market of the said Member State and Turkey.

The HA does not bring changes in components other than the SOEC in economic regulation. The other components maintain their current situation. In other words, while market access, number of airlines to enter the market, capacity and price-related regulations are negotiated with a single country (respective Member State), the party involved in negotiations on the SOEC component is the Commission, not individual countries. This situation strengthens hands of the Commission in the negotiation process. Another result is that the respective Member State is able to negotiate the dimensions and components that remain under its own control for its own sake. In other words, any third country has to negotiate with two different entities: one of them is the Member State which is the other party in the airline market, and second one is the Commission, which is a supranational institution.

Another issue that needs to be questioned is whether BASAs are still negotiated bilaterally, as its name implies. The basic philosophy has not changed. Negotiations and agreements are still made bilaterally. What has changed is that the Commission has become a party to the process. 
If a third country does not have a BASA with an EU member, this is an important issue that needs to be dealt with in the process of change. This is one of the most important criticisms that third countries bring to the HA. To exemplify, Cyprus is a Member State; let alone signing a BASA with Cyprus, Turkey even does not recognize Cyprus as a state. This has attributed a political quality to the process and remained as a crisis for long years. However, in the end, the Commission excluded Cyprus from annexes to the HA. Thus, Cyprus is still a country not recognized by Turkey. It is considered that Turkey's objection regarding this issue is a reasonable one. For, the lack of a BASA between Turkey and Cyprus means that Turkey and Cyprus has never been defined as an airline market. How can airlines enter a non-existing market or a market where they do not have the right to access?

Although the text of the HA is standard, it has been reported that the Commission carries out a different negotiation process for each country. Furthermore, the Commission had an order of priority for the negotiation of the HA (Sang-Eun Oh, 2005, p.44, 36). As neighbor countries to the EU are in the second rank, Turkey's signing the HA is of priority for the Commission.

From the legal perspective, it may be said that this change derives from the violation of legislation within the EU. On the other hand, why do third parties have to make such a change if this situation mainly concerns the EU?

\subsection{An Evaluation of BASAs between Turkey and the Member States from the Perspective of Market Entry}

There has been need for a comparison tool, in other words a scale, to evaluate the economic regulations airline markets between Turkey and EU Member States. We attempted to develop a measurement tool for the evaluation of Turkey's BASAs within the scope of a research project (Gerede, 2011, pp.29-50). During the process of developing this tool, we first surveyed the relevant literature in detail, and then identified the sub-components of each dimension, examining individually each BASA of Turkey and the memorandum of understanding that made amendments on these agreements. Subsequently, we graded these components between the tightest and the most liberal options. Market entry is one of the four dimensions of this measurement tool. The "Market Entry" dimension of this tool and its sub-components are provided below in Table 2.

Table 2. Options Regarding Market Entry and the Rating

\begin{tabular}{|c|c|}
\hline \multicolumn{2}{|r|}{ Designation of an air carrier (Three-point rating) } \\
\hline & Only a single air carrier is designated. \\
\hline \multirow{2}{*}{$\mathbf{T 2}$} & $\begin{array}{l}\text { Two air carriers are designated; but the points of access are limited, so that more than one air carrier } \\
\text { cannot operate in the same market. }\end{array}$ \\
\hline & Only two air carriers are designated. \\
\hline & Multiple designation. \\
\hline \multicolumn{2}{|r|}{ Substantial ownership and effective control in management (Three-point rating) } \\
\hline & $\begin{array}{l}\text { The substantial ownership and effective control in management need to be held by nationals of the } \\
\text { relevant party. }\end{array}$ \\
\hline & $\begin{array}{l}\text { There is not any condition concerning substantial ownership and effective control in management. } \\
\text { However, the principal place of business of the designated air carrier is required to be located in the } \\
\text { designating country, and the air carrier is required to have a valid operating license granted by the } \\
\text { designating country. }\end{array}$ \\
\hline
\end{tabular}

L The ownership and effective control in management are entirely liberal.

Source: Gerede, 2011, p.43

As seen in Table 2, the market entry dimension has two components, which are "Designation of an Air Carrier (DAC)" and "Substantial Ownership and Effective Control". In the 
first component, the tightest option (T1) in market entry is granting authorization to the entry of a single air carrier. In the face of globalized market and competition circumstances, with this tight regulation, air carriers have little chance to enter the markets that are appropriate for their competition strategies. Relatively more liberal option (T2) is granting market entry authorization to two air carriers. The option (L) that allows the designation of more than one air carrier and removes the limitations on the number of air carriers to enter a market makes this dimension entirely liberal.

The other component of this dimension, i.e. SOEC, was explained in detail in preceding parts. With regard to this component, the requirement that the principal place of business of an air carrier should be located in the other country is regarded as a more liberal regulation (T2), compared to the requirement that the ownership and effective control in management should be held by nationals of the relevant party. What makes this component fully liberal (L) is disregarding, in market entry, both nationality in ownership and effective control in management and the principal place of business.

All BASAs between Turkey and the Member States were evaluated, using the rating scale explained above. Table 3 summarizes the changes related to market entry in given countries, the initial situation and the current situation subsequent to the changes made over time.

Table 3. Initial and Current Situation in Market Entry

\begin{tabular}{|c|c|c|c|c|c|c|c|}
\hline \multirow{2}{*}{ No } & \multirow{2}{*}{ Country } & \multirow{2}{*}{ Year } & \multicolumn{2}{|c|}{ Entry } & \multirow{2}{*}{ Explanation on changes } & \multicolumn{2}{|c|}{ Entry } \\
\hline & & & DAC & SOEC & & DAC & SOEC \\
\hline 1 & Austria & 1967 & $\mathrm{~L}$ & $\mathrm{~T} 1$ & No change regarding this dimension. & $\mathrm{L}$ & $\mathrm{T} 1$ \\
\hline 2 & Belgium & 1956 & $\mathrm{~T} 1$ & $\mathrm{~T} 1$ & The BASA was renewed in 1971. & $\mathrm{~L}$ & $\mathrm{~T} 1$ \\
\hline 3 & Bulgaria & 1966 & $\mathrm{~L}$ & $\mathrm{~T} 1$ & $\begin{array}{l}\text { The BASA was renewed in } 2004 \text {; however, } \\
\text { there is no change regarding this dimension. }\end{array}$ & $\mathrm{L}$ & $\mathrm{T} 1$ \\
\hline 4 & $\begin{array}{l}\text { Czech } \\
\text { Republic }\end{array}$ & 1992 & $\mathrm{~T} 1$ & $\mathrm{~T} 1$ & The DAC was liberalized. & $\mathrm{L}$ & $\mathrm{T} 1$ \\
\hline 5 & Denmark & 1970 & $\mathrm{~L}$ & $\mathrm{~T} 1$ & No change regarding this dimension. & $\mathrm{L}$ & $\mathrm{T} 1$ \\
\hline 6 & Estonia & 1996 & $\mathrm{~T} 2^{2}$ & T1 & No change regarding the agreement. & $\mathrm{T} 2$ & $\mathrm{~T} 1$ \\
\hline 7 & Germany & 1957 & $\mathrm{~L}$ & $\mathrm{~T} 1$ & $\begin{array}{l}\text { Market access transformed from } \mathrm{T} 1 \text { to } \mathrm{T} 2 \text { in } \\
\text { 1993. Market access transformed from } \mathrm{T} 2 \text { to } \mathrm{L} \\
\text { in } 1995 . \text { However there is no change regarding } \\
\text { this dimension. }\end{array}$ & $\mathrm{L}$ & $\mathrm{T} 1$ \\
\hline 8 & Finland & 1974 & $\mathrm{~T} 1$ & $\mathrm{~T} 1$ & The DAC was liberalized. & $\mathrm{L}$ & $\mathrm{T} 1$ \\
\hline 9 & France & 1946 & $\mathrm{~L}$ & $\mathrm{~T} 1$ & No change regarding this dimension. & $\mathrm{L}$ & $\mathrm{T} 1$ \\
\hline 10 & Croatia & 1994 & $\mathrm{~L}$ & $\mathrm{~T} 1$ & No change regarding the agreement. & $\mathrm{L}$ & $\mathrm{T} 1$ \\
\hline 11 & Netherland & 1971 & $\mathrm{~L}$ & $\mathrm{~T} 1$ & No change regarding this dimension. & $\mathrm{L}$ & $\mathrm{T} 1$ \\
\hline 12 & $\begin{array}{l}\text { United } \\
\text { Kingdom }\end{array}$ & 1946 & $\mathrm{~L}$ & $\mathrm{~T} 1$ & $\begin{array}{l}\text { The BASA dated } 1946 \text { was replaced with the } \\
\text { new agreement initialed in } 2000 \text {, and was } \\
\text { liberalized. }\end{array}$ & $\mathrm{L}$ & $\mathrm{T} 1$ \\
\hline 13 & Ireland & 1980 & $\mathrm{~T} 1$ & $\mathrm{~T} 1$ & No change regarding the agreement. & $\mathrm{T} 1$ & $\mathrm{~T} 1$ \\
\hline 14 & Spain & 1974 & $\mathrm{~T} 1$ & $\mathrm{~T} 1$ & The DAC was liberalized. & $\mathrm{L}$ & $\mathrm{T} 1$ \\
\hline 15 & Sweden & 1970 & $\mathrm{~L}$ & $\mathrm{~T} 1$ & No change regarding the agreement. & $\mathrm{L}$ & $\mathrm{T} 1$ \\
\hline
\end{tabular}

${ }^{2}$ Only one air carrier can be designated in Turkey-Estonia Market. However if the designated airlines of contracting party do not operate in the same market, two airlines can be designated. 


\begin{tabular}{|c|c|c|c|c|c|c|c|}
\hline 16 & Switzerland & 1949 & $\mathrm{~L}$ & $\mathrm{~T} 1$ & $\begin{array}{l}\text { The BASA dated } 1946 \text { was replaced with the } \\
\text { new agreement initialed in 2004, and was } \\
\text { liberalized. }\end{array}$ & $\mathrm{L}$ & $\mathrm{T} 2$ \\
\hline 17 & Italy & 1949 & $\mathrm{~L}$ & $\mathrm{~T} 1$ & No change regarding the agreement. & $\mathrm{L}$ & $\mathrm{T} 1$ \\
\hline 18 & Latvia & 1994 & $\mathrm{~L}$ & $\mathrm{~T} 1$ & No change regarding this dimension. & $\mathrm{L}$ & $\mathrm{T} 1$ \\
\hline 19 & Lithuania & 1994 & $\mathrm{~L}$ & $\mathrm{~T} 1$ & No change regarding the agreement. & $\mathrm{L}$ & $\mathrm{T} 1$ \\
\hline 20 & Luxembourg & 1988 & $\mathrm{~L}$ & $\mathrm{~T} 1$ & No change regarding the agreement. & $\mathrm{L}$ & $\mathrm{T} 1$ \\
\hline 21 & Hungary & 1966 & $\mathrm{~L}$ & $\mathrm{~T} 1$ & No change regarding the agreement. & $\mathrm{L}$ & $\mathrm{T} 1$ \\
\hline 22 & Malta & 1985 & $\mathrm{~T} 1$ & $\mathrm{~T} 1$ & No change regarding the agreement. & $\mathrm{T} 1$ & $\mathrm{~T} 1$ \\
\hline 23 & Norway & 1970 & $\mathrm{~L}$ & $\mathrm{~T} 1$ & No change regarding the agreement. & $\mathrm{L}$ & $\mathrm{T} 1$ \\
\hline 24 & Poland & 1967 & $\mathrm{~L}$ & $\mathrm{~T} 1$ & No change regarding this dimension. & $\mathrm{L}$ & $\mathrm{T} 1$ \\
\hline 25 & Portugal & 1989 & $\mathrm{~L}$ & $\mathrm{~T} 1$ & No change regarding the agreement. & $\mathrm{L}$ & $\mathrm{T} 1$ \\
\hline 26 & Romania & 1966 & $\mathrm{~L}$ & $\mathrm{~T} 1$ & $\begin{array}{l}\text { Some new markets were opened to access in } \\
1997 .\end{array}$ & $\mathrm{L}$ & $\mathrm{T} 1$ \\
\hline 27 & Slovakia & 1995 & $\mathrm{~L}$ & $\mathrm{~T} 1$ & No change regarding the agreement. & $\mathrm{L}$ & $\mathrm{T} 1$ \\
\hline 28 & Slovenia & 1993 & $\mathrm{~L}$ & $\mathrm{~T} 1$ & No change regarding the agreement. & $\mathrm{L}$ & $\mathrm{T} 1$ \\
\hline 29 & Greece & 1947 & $\mathrm{~L}$ & $\mathrm{~T} 1$ & No change regarding the agreement. & $\mathrm{L}$ & T1 \\
\hline
\end{tabular}

Source: Gerede, 2012.

Table 4 shows, regarding the dimension of market entry in BASAs agreements, the situation when the agreement was first signed and the existing situation. The table surprisingly reveals that there is a liberal structure in the component of "Designation of Air Carriers" (DAC).

Table 4. General Situation of Market Entry

\begin{tabular}{|c|c|c|c|c|}
\hline & \multicolumn{4}{|c|}{ Market Entry } \\
\hline & \multicolumn{2}{|c|}{ First agreement } & \multicolumn{2}{|c|}{ Current situation } \\
\hline & DAC & SOEC & DAC & SOEC \\
\hline Tight & 6 & 29 & 3 & 28 \\
\hline More liberal & 23 & 0 & 26 & 1 \\
\hline Total & 29 & 29 & 29 & 29 \\
\hline
\end{tabular}

The countries where market entry is restricted with a single air carrier are Ireland, Lithuania and Malta. On the other hand, in 26 markets, more than one air carriers are allowed to enter the market. However, the regulation regarding the SOEC is completely opposite. In all agreements, save the one with Switzerland, the SOEC is subject to severe restrictions. This result is not surprising because, as explained above, even the US still avoids liberalizing this component.

The study made by Gerede (2012) shows that, in BASAs that Turkey signed with EU countries, all components except the market entry (market access, capacity and price setting) have been liberalized over time. The least change occurred in the SOEC component with Switzerland. This is a highly significant finding, and leads us to the conclusion that Turkey and/or Member States are reluctant to liberalize the SOEC component.

\subsection{Possible Effects of the Change on Air Carriers}

The main purpose of this study is to examine possible effects of the new situation arising with the HA on ARTs. While defining effects of the change, we will also discuss how the new situation will affect the competitive tools that air carriers frequently use. Table 5 summarizes which air carriers the change affects, results of the change, directs effects of results, and the advantages and disadvantages of these effects. 
Before the HA, a country signing the BASA could designate air carriers whose "substantial ownership and effective control in management" was held by its own nationals; whereas after the HA, this country may designate air carriers from the whole Community. This is the primary and direct effect of the HA. The indirect and most important effect of the HA is the possibility of an increase in the number of community air carriers to be designated in market that allow multidesignation. This possibility may result in increased competition, but reduced market share of ARTs. It has been reported that many Asia-Pacific countries do not lean toward the HA, seeing it as a threat to their national carriers? (Khee-Jin Tan, 2006, p.448). This change, including exclusively the Community members, does not bring any change for ARTs. That is why the change provides an advantage only to the Community Carriers.

Table 5. Effects of the Change

\begin{tabular}{|c|c|c|c|}
\hline \multicolumn{2}{|c|}{ Direct effects of the change } & \multicolumn{2}{|c|}{$\begin{array}{c}\text { Advantage - } \\
\text { disadvantage of the } \\
\text { effect }\end{array}$} \\
\hline & & $\begin{array}{l}\text { Community } \\
\text { Carriers }\end{array}$ & ARTs \\
\hline \multirow{3}{*}{$\begin{array}{l}\text { 1) All air carriers of the } \\
\text { Community may operate rather } \\
\text { than air carrier(s) designated by a } \\
\text { single country. } \\
\text { Coverage: Only air carriers of the } \\
\text { Community }\end{array}$} & $\begin{array}{l}\text { increased opportunity to enter the market for } \\
\text { the Community air carriers in liberal markets } \\
\text { that allow multi-designation }\end{array}$ & Positive & Negative \\
\hline & $\begin{array}{l}\text { increased opportunity for LCCs to enter the } \\
\text { market }\end{array}$ & Positive & Negative \\
\hline & $\begin{array}{l}\text { increased possibility for ARTs' competitors to } \\
\text { enter the markets where solely ARTs operate }\end{array}$ & Positive & Negative \\
\hline \multirow{2}{*}{$\begin{array}{l}\text { 2) As designation is open to all air } \\
\text { carriers of the Community, the } \\
\text { number of markets that the } \\
\text { Community air carriers may access } \\
\text { increases. } \\
\text { Coverage: Only air carriers of the } \\
\text { Community }\end{array}$} & $\begin{array}{l}\text { a larger flight network opportunity for } \\
\text { Community air carriers }\end{array}$ & Positive & Negative \\
\hline & $\begin{array}{l}\text { thus, an improved service quality in } \\
\text { Community air carriers }\end{array}$ & Positive & Negative \\
\hline $\begin{array}{l}\text { 3) As the SOEC liberalizes, the } \\
\text { Community air carriers may be } \\
\text { engaged in transnational mergers } \\
\text { and acquisitions among each other. } \\
\text { Coverage: Only air carriers of the } \\
\text { Community }\end{array}$ & $\begin{array}{l}\text { Airlines will be able to strengthen their capital } \\
\text { structure; make their network structure large, } \\
\text { seamless and global; merge and foster FFPs; } \\
\text { have access to the markets they could not } \\
\text { access before; have easy access to valuable } \\
\text { resources such as landing slots; invest in } \\
\text { technology; and strengthen their fleet } \\
\text { structure. }\end{array}$ & Positive & Negative \\
\hline
\end{tabular}

Another point that needs to be questioned right at this point is which of Porter's generic competition strategies the air carriers to operate in said markets will adopt (Shaw, 2007, pp.87-141). Will carriers such as British Airways and Lufthansa, which follow the differentiation strategy, or such as Rynair and Easy Jet, which follow the cost leadership strategy, enter new markets?

The entry into the airline market of air carriers, which adopt the cost leadership strategy, also known as low-cost air carriers (LCCs), may pose a significant threat to the ARTs. Such carriers operate flights to relatively shorter distances and with lower costs (O'Connell and Williams, 2005, pp.259-260; Morrell, 2005, pp.303-312; Gillen and Morrison, 2005, pp.161-174). The EuropeanTurkey markets are within the distances where LCCs operate flights. For instance, in 2011 summer tariffs, each of EasyJet (London Gatwick, London Luton and Basel) and Germanwings (CologneBonn, Stuttgart, Dortmund and Berlin) were operating 16 frequency scheduled flights in a week from Europe to Istanbul Sabiha Gokcen Airport. 
Furthermore, given that there is an intensive ethnical and tourism-oriented, price-sensitive demand in the Europe-Turkey market, the European LCCs to enter the market may meet this demand. This will have negative impacts on both Turkish Airlines and LCCs such as Pegasus. Charter airlines registered in Turkey, such as Sky and Corendon, may even be negatively affected. Moreover, Turkish Airlines, adopting a differentiation strategy, which increases costs, may have difficulty in competing with the LCCs, which adopt a low cost strategy. For, customers sensitive to prices would prefer the LCCs.

Another negative consequence on Turkish Airlines and other ARTs will be the entry of competitors to the markets, where these air carriers are strong as being the exclusive operators in these markets. For instance, in the Czech Republic-Turkey market, only Turkish Airlines operates scheduled flights. In the aftermath of the HA, a Community air carrier designated by a Member State may enter this market.

Such an increase in competition after the HA may also have positive impacts on the ARTs. For, the HA will liberalize only the SOEC component. However, when Turkey acquires full accession to EU, all tight economic regulations will be removed. The fact that the ARTs get used to competition in this transition period is important for Turkey to achieve sustainable success. Furthermore, as emphasized above, in case of liberalization in the market and subsequent increase in competition, the demand is inclined to increase. If we take advantage of this increase as a country, it is possible to say that the demand in the Turkey-Europe airline market, the number of foreigners visiting Turkey, the traffic in Turkish airports, and hence aviation and tourism incomes will be augmented.

On the other hand, it is not always possible for other Community airlines to enter the same market. For example, provided that a single air carrier is authorized to enter and that the other party of an agreement already uses this right, a second air carrier cannot enter this market unless the BASA is amended. Or, the capacity of a given market may have been shared by civil aviation authorities or airlines operating in the said route. If this limited capacity is used mutually, the entry of a third Community air carrier into the market will not affect the ARTs significantly. For, the capacity right granted to the opposing party will be shared by two Community air carriers. However, provided that a second ART demands entering this market, then the other party of the agreement may use this demand as a topic of negotiation, and impose the liberalization of both capacity and access as a prerequisite. A liberal and unrestricted capacity may render the market attractive for new Community air carriers, but will be a threat for the ARTs.

Another effect of the HA will be on the dimension of market access. As explained before, the HA does not bring any changes to the components other than the SOEC. Still, it may be said that the HA has accrued market access opportunity of Community air carriers. For the markets that could not be accessed due to SOEC regulations will start opening after the HA. To exemplify, it will be easier for Lufthansa to operate flights on the Prague-Istanbul-Prague route. What is exemplified here is the seventh traffic right, which is strictly forbidden in traditional BASAs. Yet, the HA does not provide access to the markets which the third party airlines, such as ARTs, may wish to enter, but cannot enter because of tight regulations.

As the Community air carriers increase the number of markets they have right to access (the number of city pairs to which they provide service), they have a larger flight network. This means that customers move from one place to another more freely; in other words, airlines meet and even go beyond customers' demands and needs. Air carriers produce transportation services on their flight network, and thus the structure of network is very important for improving quality. As mentioned above, an appropriate network structure is an important strategic tool for airlines. The HA does not bring any change on market access of the airlines of third countries such as ARTs. That is why the explained effects seem to create an advantage only for the Community air carriers.

Undoubtedly, another direct effect of the HA will be transnational mergers and acquisitions among the Community air carriers. The carriers that easily use this strategy may strengthen their 
capital structure; make their network structure large, seamless and global; merge and foster Frequent Flyer Programs (FFPs); have access to the markets they could not access before; have easy access to valuable resources such as landing slots; invest in technology; and strengthen their fleet structure (Hanlon, 2007, p.298; Doganis, 2006, p.58). These are competition strategies that may provide an airline with significant advantages. Thus, mergers and acquisitions are very important strategic competition tools for air carriers. The HA does not liberalize this component for airlines in the third countries such as ARTs, and this situation worsens the said negative effects.

Researching the effects of the HA on Asia-Pacific countries, Khee-Jin Tan (Khee-Jin Tan, 2006, pp.432-433) does not see as a threat the increase in the number of the Community air carriers in the market. He emphasizes that the real threat derives from competition with an air carrier that merges with others in the market and becomes stronger (Khee-Jin Tan, 2006, pp.450-451). Only the Community airlines may use transnational merger and acquisition strategies.

Notwithstanding the above explained negative effects of the HA on ARTs, it is estimated that there will be a growth in the European-Turkish airline market. This effect can be the result of reduction in ticket prices and/or an improvement in service quality. However, on condition that the ARTs have to withdraw from the market due to the abovementioned negative effects before Turkey becomes a member to the EU, Turkey will be perturbed by the anxiety to assure national security, just like the US. Furthermore, the withdrawal of ARTs from the market may result in duopoly or monopoly in the market, and remove the public benefit explained above.

In the process of Turkey's negotiations for accession, we believe that the Commission has a stronger hand. Since 2005, the Commission has taken every opportunity to express that the HA must be signed, and also includes this requirement in Progress Reports. For instance, in 2005, in negotiations to make BASAs with Austria and the UK more liberal, both countries indicated that they would not amend the agreements unless the existing agreements were amended in line with the Commission's conditions. However, in that year, the Ministry of Transport declared that a more liberal market with both countries would be to the advantage of Turkey. Turkey may have a stronger hand in liberalizing any market in Europe after signing the HA, and this may be regarded as one of the positive effects of the HA.

In the light of the above explanations, we may conclude that the HA is expected to have direct impacts on such frequently used competitive tools as flight network structure, and merger and acquisition strategies. The HA may indirectly influence price and technology strategies. Each strategy is explained individually below. This analysis may be helpful for the ARTs to design appropriate competitive strategies, using Porter's Five Forces Analysis.

Flight Network: The Community air carriers will be able to increase the number of destination points in Europe owing to the HA. This increase may certainly create a flight network that better meets the demands and needs of customers. Offering services to a greater number of destination points and a larger geographical area is a significant competitive strategy (Hanlon, 2007, p.313; Gerede, 2002, pp.104-110).

Mergers and Acquisitions: We have explained above the HA offers great flexibility to the Community airlines with respect to this strategy. This will certainly assure an important competitive advantage for these airlines.

Price: In the aftermath of the HA, it is expected that the number of air carriers in some markets, in other words the number of potential competitive threats, will increase. If price setting is regulated liberally in the said markets, price may be used as a competitive tool therein. The data obtained in this study show that, even if the market is not liberal in terms of price tariffs, price setting may be liberal in practice. Thus, price competition will increase and the ARTs will be affected negatively, if the LCCs in the Community enter these markets.

Flight Frequency and Departure Time: The HA is not expected to have direct effects on this strategy. Nevertheless, it should not be disregarded that the air carriers newly entering the 
market will use both price and flight frequency as a competition tool in order to survive in the market, provided that the capacity component is liberal in the market where the Community airlines gain access after the HA. Flight frequency is a very important determining factor in demands of particularly passengers flying for business purposes (Doganis, 2002, pp.238-241; Hanlon, 2007, p.85; Wensveen, 2007, p.188).

Loyalty Programs: At first sight, the HA does not seem to affect this strategy directly. However, the success of loyalty programs, as a very important competitive strategy, is dependent upon the existence of a large and seamless flight network (Gerede, 2002, pp.114-115). If the HA increases market access opportunities and hence enhances the flight network, the Frequent Flier Programs (FFPs) of the Community carriers may assure more loyalty compared to those of the ARTs. This provides the former with an important competitive advantage.

Computerized Reservation Systems: The HA is not expected to have a direct effect on this strategy. However, if the HA ensures the entry of more Community air carriers into the European Turkish airline market, then it is likely that more Community carriers appear in the first ranks and pages of the CRS screen. Being placed on first pages of CRS screen increases ticket sales, particularly in sales from tourist agencies (Holloway, 2002, p. 25). Yet, today, the existence of more conscious customers and internet-based sale services is expected to reduce the negative effects.

Human Resources and Innovation: The HA is not expected to have a direct effect on these strategies. Yet, in the face of growing competition, the ARTs are required to be innovative and use human resources effectively and efficiently in order to gain competitive advantage.

Technology: The Community air carriers, able to use merger and acquisition strategies more easily, may appropriate funds for technological investments, where required.

\subsection{Opinions of Air Carriers in Turkey on the HA and its Possible Effects}

In this study, we first conducted literature survey and provided a theoretical ground to analyze the changes that the HA is expected to bring. But, the opinions of the ARTs on this issue are also very important. That is why the ARTs that operate scheduled flights in the Turkey-Europe airline market have been taken into the scope of this study. By May 2011, these air carriers were Turkish Airlines, Pegasus and SunExpress. We further received the opinion of the TPAEA

\subsubsection{Opinions of the TPAEA}

According to the TPAEA, the change that will create the most significant effect is that an air carrier launched in any EU country may be easily designated by another country. It is very easy for an air carrier to open a "Branch Office" in the country that will designate this carrier. In the event of the lack of capacity restrictions, this change will enhance the opportunity of the Community carriers to enter the market from whichever country they wish, and lead to an unfair competitive environment to the detriment of the ARTs. That is why the TPAEA regards multi-designation, which brings more liberalization to BASAs, as a threat for the Turkish Airline Industry. In the case that entry to the market is liberal, third-party countries may enter the market easily. Yet, air carriers such as Pegasus and SunExpress, aspiring to grow in Europe, request more liberal BASAs, considering the existing market dynamics. This demand puts these carriers into a self-contradictory situation. As a result, the TPAEA believes that the sector vacillates between the demand for a larger capacity to grow and the threat posed by the HA. It seems that the private sector sides with liberalization, but fears that the HA may be to the disadvantage of the ARTs.

The TPAEA further argues that the degree of threat will intensify when strong Low cost air carriers (LCACs) of the Community enter the market, which is highly possible according to the TAPSAC. Another important viewpoint of the TPAEA is that the process of membership is expected to take about 15 years, but the HA is expected to enter into force immediately, which is unfair for the ARTs. 
The TPAEA is aware that the HA will increase market entry possibility of the Community air carriers. This change will provide the Community carriers with the opportunity to promote and enhance their flight network and design their networks more effectively and efficiently. Furthermore, because all air carriers in the Community will have the chance to be designated by all Member States, there will be a considerable difference between airplane numbers in the fleets of the ARTS and the Community carriers, the TPAEA envisages. According to the TPAEA, a larger fleet will assure an unfair competitive advantage to the Community carriers. In 2010, the number of Community carriers, which were members of the IATA was 73, while the number of the ARTs was only 4 (Kaplan, 2010, p.93). Finally, the TPAEA believes that the HA will not have any positive effects for the ARTs.

Furthermore, despite the existence of multi-designation opportunity in some markets, the Directorate-General of Civil Aviation of Turkey avoids designating the private ARTs, and this situation poses an unfair competitive environment to the advantage of the Turkish Airlines and to the disadvantage of the ARTs, the TPAEA argues.

\subsubsection{Opinions of Pegasus Airlines}

The interview data show that Pegasus fully agrees with the negative effects predicted by the TPAEA. Pegasus additionally draws attention to another negative effect of the HA. Most airports in the EU are closed at nights due to noise regulations whereas all Turkish airports are open. Given that the HA provides the Community air carriers with entry to more markets and with more entry rights and that these carriers have a larger fleet compared to the ARTs, night flights will increase the efficacy of their airplanes and decrease unit costs. Thereby, the Community carriers will be able to design and operate their flight networks more effectively, and gain a significant competition advantage.

Agreeing with the TPAEA, Pegasus argues that the new Community air carriers to enter the market will mostly be LCCs. But, for Pegasus, the real threat derives from the fact that these carriers may use Turkey a base.

Pegasus, although believing that the HA does not have any positive effects on the ARTs, considers that the HA will increase the demand in the Turkey-Europe airline market, the number of foreigners visiting Turkey, and the traffic in Turkish airports. Although the HA poses greater threats to the markets where regulations on capacity and market entry are liberal, Pegasus suggests that the Turkey- Europe airline market should be more liberal, on contrary to the TPAEA's opinions.

\subsubsection{Opinions of SunExpress Airlines}

SunExpress Airlines also agrees with the opinions and analyses of the TAPSAC. SunExpress argues that the HA will be a one-sided and unfair source of competition in favor of the Community carriers, and that the HA does not include any provisions that may be regarded as a positive development or gain from the perspective of the ARTs.

\subsubsection{Opinions of Turkish Airlines}

The opinions of Turkish Airlines on the HA is important as this air carrier employ differentiated strategic competitive tools and seems more advantageous compared to other ARTs. The differences of Turkish Airlines may be summarized as follows: a larger flight network particularly thanks to STAR Alliance, the use of Hub\&Spoke $(H \& S)$ network structure in domestic and international routes (accordingly the Istanbul-Europe market is substantially fed by other regions), a much more effective FFP owing to the advantage of flight network strategy, a larger fleet structure, and a well-proven service quality.

Given these differences, Turkish Airlines is not expected to take serious the negative impacts of the HA as much as private ARTs. However, contrary to this expectation, Turkish Airlines perceives the HA as a serious threat, in parallel with the opinions of the TPAEA. Turkish Airlines has recently been faced with the entry into the Turkey- Europe market of new ARTs with 
the liberalization of airline designations, and is now anxious that other Community air carriers will enter the same market. The fact that newcomers to the markets may mostly be LCCs multiplies this anxiety. It seems that Turkish Airlines is not willing to compete with the LCCs of the Community.

\section{Conclusion and Recommendations}

The BASAs between Turkey and Member States will not be subject to an amendment on condition that the HA is signed. Nevertheless, after the signing of the HA, the ownership and effective control in management of the air carriers, which will use the right to market entry, may be held by nationals of any Member State. The HA liberalizes the SOEC component of market entry, which has been regulated very tightly across the world. The liberalization is unilateral, and its scope is restricted to the Community air carriers. As a result of the HA, the Community carriers will accrue the number of markets they access, and be engaged in transnational mergers and acquisitions among each other. These are expected to provide the Community carriers with important strategies and strategic advantages.

The findings of this study show that the ARTs, which participated in this study, are aware of implications of the HA. The TPAEA and the ARTs believe that the existing provisions in the HA do not have any positive effects on the ARTs. With the HA, their competitors will have easier access and entry to the market, and thus obtain a flight network that better meets the demands and needs of customers. After the signing of the HA, the competitors will be able to foster their capital structure; make their network structure large, uninterrupted and global; merge and foster their FFPs; have access to the markets they could not access before; have easy access to valuable resources such as landing slots; invest in technology; and strengthen their fleet structure, since they will be able to use transnational merger and acquisition strategies easily. All these are competition strategies that air carriers use in liberal markets. When they effectively use these strategies, the Community air carriers will inevitably gain significant strategic advantages over the ARTs.

Under these circumstances, the following may be recommended with regard to the signing of the HA:

1. The signing of the HA may be postponed and reconsidered in line with the progress in Turkey's access to the EU process.

2. If the HA is signed before Turkey's access to the EU, measures to protect the ARTs from the unfair competitive environment may be taken. For instance, additional slots may be demanded for the ARTs, which cannot enter European airports due to lack of capacity.

3. In liberal markets, measures may be taken against unbalances to emerge in the amount of production after the HA.

4. In the entry of Community airlines to liberal markets, priority may be given to second-party airlines rather than to third-party airlines.

5. In order to repair the principle of "mutuality", it may be enabled that the parties enjoy the advantages of a liberal market mutually, as soon as possible and before waiting for Turkey's access to the EU.

6. This study attempts to identify the potential competitive strategies to be used by the Community airlines and new powers to emerge, if the HA is signed. In consideration of the analyses in this study, the ARTs may closely work on Porter's Five Forces Model and possible competitive strategies of their competitors, and develop strategies in line with these analyses and examinations. 


\section{References}

Alamdari, F. E. \& Morell, P. (1997). Airline Labour Cost Reduction: Post-Liberalisation Experience in the USA and Europe. Journal of Air Transport Management, 3, 53-66.

Antoniou, A. ( 2001). The Air Transportation Policy of Small States: Meeting the Challenges of Globalization. Journal of Air Transportation World Wide, 6, 65-92.

Belobaba, P., Odoni, A. \& Barnhart, C.(2009). The Global Airline Industry, West Sussex, UK: John Wiley \& Sons.

Brueckner, J. K. \& Pels, E. (2007). Institutions, Regulation, and the Evolution of European Air Transport, in: Lee, D. (Ed.), The Economics of Airline Institutions, Operations and Marketing, 2, Amsterdam: Elsevier.

Button, K., Haynes, K. \& Stough, R. (1998). Flying into the Future: Air Transport Policy in the European Union, Cheltenham, UK: Edward Elgar.

Chan, D. ( 2000). The Development of the Airline Industry from 1978 to 1998: A Strategic Global Overview. Journal of Management Development, 19, 489-514.

Chang, YC., Williams, G. \& Hsu, CJ. (2004). The Evolution of Airline Ownership and Control Provisions. Journal of Air Transport Management,10, 161-172.

Chang, YC. \& Williams, G. (2002). European Major Airlines' Strategic Reactions to Third Package. Transport Policy ,9, 129-142.

Çetinkaya, O. (2009). Examining the Opportunities and Strategies for Turkey's Carriers as the Country Liberalizes its Air Transport Market with the EU. Unpublished master's thesis, Cranfield University, Cranfield, UK.

Doganis, R. (2002). Flying off Course: The Economics of International Airlines, third ed. Routledge, London.

Doganis, R. (2006). The Airline Business, second ed. Routledge, London.

Dresner, M. \& Oum, T.H. (1998). The Effect of Liberalized Air Transport Bilaterals on Foreign Traffic Diversion. Journal of Transport Economics and Policy, 32, 317-330.

Elek, A., Findlay, C., Hooper, P. \& Warren, T. (1999). Open Skies or Open Clubs? New Issues for Asia Pacific Economic Cooperation. Journal of Air Transport Management, 5, 143-151.

European Parliament and the Council (2008). Regulation (EC) No 1008/2008 on Common Rules for the Operation of Air Services in the Community. Retrieved December 14, 2011. $<$ http://eurlex.europa.eu/LexUriServ/LexUriServ.do?uri=OJ:L:2008:293:0003:0020:EN:PDF>.

Findlay, C. (2003). Plurilateral Agreements on Trade in Air Transport Services: the US Model. Journal of Air Transport Management, 9, 211-220.

Forsyth, P. (1998). The Gains from the Liberalization of Air Transport. Journal of Transport Economics and Policy, 32, 73-92.

Forsyth, P. (2001). Promoting Trade in Airline Services. Journal of Air Transport Management, 7 , 43-50.

Gerede, E. (2002). Havayolu Taşımacılı̆̆ında Küreselleşme ve Havayolu İşbirlikleri THY A.O. 'da Bir Uygulama [Globalization in Airline Industry and Airline Alliances - A Case Study at Turkish Airline]. Unpublished Doctoral Thesis, Anadolu Universtiy/Social Sciences Institute, Eskişehir, Turkey.

Gerede, E. (2004). Türk Havayolu Taşımacılığının Bugünü ve Yarını: Uluslararası Havayolu Taşımacılığındaki Gelişmeler ve Avrupa Birliği Perspektifi [The Present and Future of Turkish Airline Industry: the Developments in International Air Transportation and the Perspective of 
European Union]. 2004 Türkiye İktisat Kongresi, İktisadi Sektörlerde Gelişme Stratejileri Tebliğ Metinleri-II, 275-308.

Gerede, E. (2011). Türkiye'nin İkili Havayolu Taşımacılığı Anlaşmalarının Havayolu Yönetimine Etkileri Açısından Değerlendirilmesine Yönelik Bir Ölçek Önerisi. [Proposal of a Scale for Evaluating Bilateral Air Services Agreements of Turkey Regarding Their Effects on Airline Management]. Anadolu Üniversitesi Sosyal Bilimler Dergisi, 11, 29-50.

Gerede, E. (2012). Avrupa Birliği'ne Tam Üyelik Sürecinde Türkiye - Avrupa Birliği Havayolu Pazarındaki Ekonomik Düzenlemelerin Havayolu Yönetimine Etkisi Açısından İncelenmesi [Analyzing the Economic Regulations in Turkey - EU Airline Market in the Accession Process to EU in an Airline Management Perspective]. Akdeniz Üniversitesi İktisadi ve İdari Bilimler Fakültesi Dergisi, 12, in press.

Gillen, D. \& Morrison, W. G. (2005). Regulation, Competition and Network Evolution in Aviation. Journal of Air Transport Management, 11, 161-174.

Graham, B. (1997). Regional Airline Services in the Liberalized European Union Single Aviation Market. Journal of Air Transport Management, 3, 227-238.

Haanappel, P.P.C. (2001). Airline Ownership and Control and Some Related Matters. Air\&Space Law, 16, 90-103.

Hanlon, P. (2007). Global Airlines: Competition in a Transnational Industry, third ed. Butterworth-Heinemann, Amsterdam: Elsevier.

Holloway, S. (2002). Airlines: Managing to Make Money, Aldershot, UK: Ashgate,.

European Commission (2006). Draft Horizontal Agreement. Working Paper. Retrieved December 14, 2011. http:/ec.europa.eu/transport/air/international_aviation/doc/draft_horizontal_agreement_en.pdf.

ICAO, (1999). Policy and Guidance Material on the Economic Regulation of International Air Transport, second ed. Doc. 9587.

ICAO, (2004). Manual on the Regulation of International Air Transport, second ed. Doc. 9626.

Kaplan, L. (2010). Yatay Anlaşmaların Sivil Hava Yollarına Etkileri [Effects of Horizontal Agreement on Airlines]. Avrupa ve Türkiye'de Hava Hukuku Konusunda Son Gelişmeler, İstanbul: Koç Üniversitesi Hukuk Fakültesi, Dr. Nüsret-Semahat Arsel Uluslararası Ticaret Hukuku Uygulama ve Araştırma Merkezi Konferans Yayınları Dizisi-3.

Kassim, H. \& Stevens, H. (2010). Air Transport and the European Union Europeanization and its Limits, New York: Palgrave Macmillan

Khee-Jin Tan, A. (2006). Liberalizing Aviation in the Asia-Pacific Region: the Impact of the EU Horizontal Mandate. Air\&Space Law, 31, 432-454.

Maillebiau, E. \& Hansen, M. (1995). Demand and Consumer Welfare Impacts of International Airline Liberalisation. Journal of Transport Economics and Policy, 29, 115-136.

Melville, J. A. (1998). Identifying the Regulatory Effect of Bilateral Agreements on International Aviation. Journal of Air Transport Management, 4, 39-46.

Mestral, A. (2005). Canadian-EU Bilateral Air Services Agreements, The McGill / Concordia Report on International Aviation Policy for Canada. Retrieved December 14, 2011. http://www.iee.umontreal.ca/publicationseng_fichiers/DIVERS/Accord-bilat\%C3\%A9ral.pdf.

Morrell, P. (1998). Air Transport Liberalization in Europe: the Progress so far. Journal of Air Transportation World Wide, 3, 42-60. 
Morrell, P. (2005). Airlines within Airlines: An Analysis of US Network Airline Responses to Low Cost Carriers. Journal of Air Transport Management, 11, 303-312.

O’Connell, J. F. \& Williams, G. (2005). Passengers' Perceptions of Low Cost Airlines and Full Service Carriers: a Case Study Involving Ryanair, Aer Lingus, Air Asia and Malaysia Airlines. Journal of Air Transport Management , 11, 259-272.

O’Connor, W. E. (1995). An Introduction to Airline Economics, fifth ed. Westport: Praeger.

Oum, T.H. \& Yu, C. (1998). Winning Airlines: Productivity and Cost Competitiveness of the World's Major Airlines, Boston: Kluwer Academic Publishers.

Özsoy, G. (2010). Türk Havayolu Işsletmelerinin 2003 Iç Hat Serbestleşmesine Verdikleri Stratejik Tepkiler [The Strategic Responses of the Turkish Airline Companies to the Deregulation of Domestic Air Transportation in 2003]. Unpublished master thesis, Anadolu University / Social Sciences Institute, Eskişehir, Turkey.

Sang-Eun Oh, J. (2005). The EU Horizontal Agreements: Background and Consequences of an Air Political Novum. Unpublished master thesis, McGill University Faculty of Law, Institute of Air And Space Law, Montreal.

Shaw, S. (2007). Airline Marketing and Management, sixth ed. Aldershot: Ashgate.

Sheth, J. N., Allvine, F.C., Uslay, C. \& Dixit, A. (2007). Deregulation and Competition: Lessons from the Airline Industry. New Delhi: Response Books.

Sinha, D. (2001). Deregulation and Liberalisation of the Airline Industry. Hampshire: Ashgate.

Staniland, M. (1997). Surviving the Single Market: Corporate Dilemmas and Strategies of European Airlines. Journal of Air Transport Management, 3, 197-210.

Wensveen, J. G. (2007). Air Transportation: A Management Perspective, sixth ed. Aldershot: Ashgate.

Wolf, H. (1998). Network Effects of Bilaterals: Implications for the German Air Transport Policy. Journal of Air Transport Management , 7, 63-74.

Zhang, A. \& Chen, H. (2003). Evolution of China's Air Transport Development and Policy Towards International Liberalization. Transportation Journal, 42, 31-49. 